\title{
O SABER DO DESEJO PRATICADO NOS COLETIVOS PARENTAIS
}

\author{
Maria Vitória Campos Mamede Maia ${ }^{\mathrm{i}}$ \\ Eduarda Silveira dos Anjos Bainhaii
}

\begin{abstract}
Resumo: O presente artigo traz o recorte de uma pesquisa maior realizada em dois coletivos parentais que atuam no Estado do Rio de Janeiro, com uma proposta de educação que desenvolve a autonomia de seus participantes. Para a discussão teórica, Fernández (2001) é apresentada sobre autoria de pensamento. Nestes espaços, o livre brincar é a base do processo de aprender, e é a partir dele que os sujeitos dão voz às suas autorias. Sendo a pesquisa de cunho qualitativo, a construção metodológica se baseou no tipo etnográfico adaptado à educação (ANDRÉ, 2009). Para a análise dos dados foi utilizada a técnica de análise de conteúdo temática de Bardin (2016). Os resultados apontaram para a importância de um ambiente lúdico na educação e o quanto este colabora para a formação de sujeitos desejantes.
\end{abstract}

Palavras-Chave: Autoria de Pensamento; Coletivos Parentais; Criatividade.

\section{THE KNOWLEDGE OF DESIRE PRACTICED IN PARENTAL COLLECTIVES}

\begin{abstract}
This article presents the outline of a larger research carried out in two parental collectives that work in the State of Rio de Janeiro, with an education proposal that develops the autonomy of its participants. For theoretical discussion, Fernández (2001) is presented on thought authorship. In these spaces, free play is the basis of the learning process, and it is from it that the subjects give voice to their authorship. Since the research is qualitative, the methodological construction was based on the ethnographic type adapted to education (ANDRÉ, 2009). For data analysis, the technique of thematic content analysis by Bardin (2016) was used. The results pointed to the importance of a playful environment in education and how much it contributes to the formation of desiring subjects.
\end{abstract}

Keywords: Thought Authorship; Parental Collectives; Creativity.

\section{Introdução}

Coletivos parentais, creches parentais, creches domiciliares ou coletivos de cuidados são alguns dos nomes dados a uma emergente forma de educação não formal, impulsionada pelas famílias, cujo foco é a primeira infância. Na visão de educadores que atuam nestes espaços, a grande diferença está na hierarquização destes lugares. É possível distinguir um coletivo de uma creche parental porque na segunda, a hierarquização quase sempre é mantida, quando um grupo de pais contrata uma educadora no lugar da contratação de uma escola, porém se mantém a mesma relação verticalizada professor-aluno de uma instituição formal 


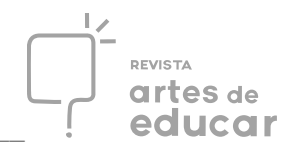

(CHAMUSCA, 2009). Já um coletivo parental se funda quando diversas famílias buscam uma alternativa de educação para seus filhos em idades não escolares, que possam vir ao encontro de suas crenças e modo de vida. Normalmente, essas crenças convergem no que tange à liberdade e ao respeito à individualidade das crianças.

Podemos entender a educação não formal como processos de autoaprendizagem e aprendizagem coletiva conquistada por experiências em ações organizadas pela sociedade com eixos temáticos como questões etnicorraciais, de gênero, geracionais etc. As práticas destes espaços se desenvolvem fora do ambiente escolar, pautados em uma formação sobre direitos humanos, cidadania, práticas identitárias, lutas contra desigualdades, entre outros temas sociais (GOHN, 2009). Sendo assim, os coletivos parentais surgem como uma alternativa ao sistema educacional imposto, com a proposta de levar para o processo educativo das crianças conceitos mais respeitosos de cidadania, liberdade, inter-relação e sustentabilidade.

Desta forma, para compreender se estes espaços alcançam uma educação voltada para a autoria de pensamento, foram selecionados dois coletivos parentais, seguindo dois critérios de escolha: que os coletivos possuíssem espaço próprio e não atuassem dentro das casas das famílias; e que tivessem educadores contratados responsáveis pelas atividades diárias das crianças. Foram encontrados dois coletivos que se encaixavam nos critérios adotados, um que ainda se denomina assim e outro que se transformou, no último ano, em um projeto de Educação Psicomotora, mas que apresentam falas muito próximas a esse conceito de educação não formal pautada em ideais familiares.

O primeiro espaço de educação pesquisado se chama Coletivo CasaEscola. Este atua desde 2013, em Santa Teresa, na cidade do Rio de Janeiro e se define em seu blog como:

Um coletivo de pais e mães que tem como objetivo construir um espaçotempo educativo e de cuidado para crianças e pais que privilegie o desenvolvimento corporal, cognitivo e espiritual de cada participante, respeitando assim os ritmos individuais, a diversidade e estimulando a convivência com o coletivo e com a natureza. (COLETIVO CASAESCOLA, 2017, disponível em: http://casaescolarj.blogspot.com/ acesso em 20/08/2020)

As atividades da CasaEscola acontecem três vezes por semana em um espaço próprio deles, chamado de "Castelo", e, duas vezes por semana, o coletivo ocupa algum lugar público como espaço cultural, museu, praça, praia etc. $\mathrm{O}$ grupo das crianças maiores e o grupo das 
crianças menores, como assim são chamados, se revezam nos dias de estarem em passeio ou no espaço do coletivo. Para a pesquisa foi acompanhado o grupo dos maiores.

O coletivo permeia a vida dessas famílias em todas as esferas, não só no momento em que estão dentro do espaço ou nos passeios. Existe um sistema criado de vida que engloba aquelas famílias em muitos aspectos. As crianças parecem pertencer a uma comunidade, e pode-se perceber como elas se sentem responsáveis por esse sistema.

O "Castelo", como assim é chamado o prédio em que fica a sede do coletivo, devido ao formato da sua construção, possui dois espaços para uso deste. O local é, na verdade, um prédio residencial, porém como uma moradora é integrante do coletivo, conseguiu, em seu espaço, dois locais para locação das atividades. Um destes é fechado, onde normalmente fica o grupo dos menores e o outro é o terraço do prédio, ocupado, na maioria das vezes, pelo grupo dos maiores.

Os dois ambientes são repletos de materiais disponíveis para as crianças, como tinta, lápis, papel, tesoura, cola, materiais recicláveis, instrumentos musicais, pneus, mobílias antigas, almofadas, panelas, ou seja, uma infinidade de objetos que são transformados ao longo do dia com a intervenção das crianças. No espaço fechado há um trapézio pendurado no teto, ao passo que no terraço existem várias cordas e tecidos pendurados também à disposição das crianças. Há, ainda, no terraço, uma piscina vazia, que se transformou em um local de experimentação. Seus azulejos são manchados de tinta, existe uma estrutura de corda para as crianças subirem e, por muitas vezes, ela também se torna uma quadra para jogo de bola.

O segundo espaço pesquisado, o Projeto Rizoma, atua no bairro de Pendotiba, na cidade de Niterói, RJ. Ele surgiu da divisão de um coletivo parental chamado Casa Viva que atuava desde o ano de 2013. No final do ano de 2018, as famílias encontraram algumas divergências para a continuidade do coletivo e resolveram, então, reconstruir o espaço com uma nova configuração. O Rizoma, hoje, se identifica como um projeto de Educação Psicomotora e tem, em sua proposta de aprendizagem, atividades com equitação, música, além do livre brincar como base de sua proposta educativa.

O Coletivo Casa Viva aconteceu por cinco anos e, após esse período, com o crescimento das crianças, os pais sentiram a necessidade de criar um outro formato para conseguir atender às novas demandas delas. De acordo com um dos fundadores do projeto, o coletivo parental fez sentido enquanto os filhos eram bebês e eles se revezavam nos cuidados daquelas crianças. À medida que os filhos foram crescendo, alguns pais eram somente pais, surgindo, assim, a necessidade de trazer outras pessoas, profissionais, que pudessem dar conta do que era exigido pela nova fase dos pequenos. 
Ao contrário da CasaEscola, os encontros da Casa Viva não tinham um educador responsável e, quando a idade das crianças começou a exigir atenção especializada, a sustentação dada pelas famílias se tornou insuficiente. Por isso, se esta pesquisa entende coletivos parentais como uma configuração de educação em que famílias buscam alternativas em que os filhos tenham contato com propostas que vão ao encontro de suas crenças e modos de vida, o Projeto Rizoma se enquadra nos moldes dos coletivos parentais.

A diferença mais ampla entre o Rizoma e a CasaEscola é o fato de não haver, no primeiro, uma escala de pais para os cuidados diários das crianças. Existem duas pedagogas e uma cuidadora fixas, contratadas pelos responsáveis pelo projeto. Estes responsáveis são um casal de psicomotricistas, que tem uma filha participante do projeto, e um pai de duas crianças atuantes do projeto, professor de Matemática e que está se formando em Psicomotricidade. Todos eles também foram os idealizadores do coletivo em 2013.

O projeto, portanto, é composto por pais atuantes, porém não são todos os pais que participam. As outras famílias do Rizoma não fazem parte do dia a dia das crianças, porém podem acompanhar as atividades se quiserem. O espaço é aberto para a circulação dos pais, alguns têm o hábito de tomar café junto com os filhos no local antes de deixá-los. As decisões a respeito de atividades, passeios, também são feitas em conjunto, com todas as famílias e elas se sentem livres em opinar e decidir. A proximidade dos pais, tanto no espaço físico como no modo de exercer a educação no projeto, também é um dos fatores que fez com que se optasse por manter o Rizoma definido como um coletivo.

Essa quebra de hierarquização é uma forma de entender que estas famílias atuam coletivamente na decisão sobre a educação dos filhos e, o fato de haver pedagogas contratadas, não retira deste lugar a tentativa de horizontalidade das decisões. Na CasaEscola, por exemplo, também existem as educadoras contratadas, algumas são mães do coletivo e outras não. Mas como os processos educativos são criados coletivamente, não existe a sensação de submissão de poderes.

O espaço físico do Rizoma é amplo, pois ali também existe um projeto de equoterapia, por isso o cenário lembra muito o de uma fazenda, apesar de ser menor e estar inserido dentro da cidade de Niterói. Logo ao entrar, vemos um grande campo de areia, cercado, onde acontecem as atividades com os cavalos. Ao fundo, o estábulo e, na lateral, outro espaço de terra com casinha de madeira, objetos de pintura, brinquedos, cordas, pneus etc. As paredes deste local são cheias de tintas, que formam desenhos e escritas. Em frente desta parte de areia, existe uma cozinha e um banheiro. Ao fundo, uma escada que dá acesso a uma sala 
fechada ampla, com almofadas e poltronas. Na parte de trás da construção, há um espaço de mata que as crianças também ocupam quando sentem vontade.

\section{Metodologia}

A metodologia adotada pela pesquisa é a pesquisa tipo etnográfica (ANDRÉ, 2009), com uma abordagem qualitativa, de objetivo exploratório e de natureza aplicada. Foram utilizados como instrumentos de coleta de dados a observação direta, o diário de campo e a entrevista semiestruturada. A análise de conteúdo proposta por Bardin (2016) foi o método escolhido para a análise dos dados.

Uma das categorias que surgiu na análise de dados foi a denominada "O Sujeito Desejante", escolhida para este artigo por discutir o quanto o desejo do sujeito, ao ser acolhido, colabora para o processo de aprendizagem que desenvolve a autonomia e autoria de pensamento dos aprendentes. Para a recolha de dados para a pesquisa aqui relatada, na categoria escolhida, foram utilizados o diário de campo construído durante a observação participante, e as entrevistas semiestruturadas, envolvendo pais e educadoras que fazem parte dos coletivos pesquisados.

Ao todo, a pesquisa abarcou dez entrevistas, sendo elas: três de educadoras e sete de responsáveis pelas crianças. Destas três educadoras, uma é mãe e fundadora de um dos coletivos. Já entre os pais, três deles atuam como profissionais no outro coletivo e também o fundaram, porém se sentiram mais a vontade de responder a entrevista como pais, mais do que como educadores.

Essas vozes se confundem, por muitas vezes, entre pais e educadores, entre profissionais e famílias, e isso é mesmo uma característica que define estes sujeitos enquanto atuantes dos coletivos. Por serem parte destes projetos que tratam da educação de seus filhos, esses pais se colocam no lugar também de educadores e de aprendizes, como se todos ali atuassem em todas as posições. Aliás, as educadoras que não possuem filhos nos projetos também deixam claro a ideia de que estão em constante processo de aprendizagem.

Foram, portanto, estas vozes que construíram essa discussão, além das crianças observadas durante a pesquisa participante. São famílias que possuem algum conhecimento a respeito da educação ou do desenvolvimento infantil, evidenciado em suas formações e que, juntas, criaram uma nova forma de educar seus filhos. São ainda profissionais da educação 
que se viram buscando alternativas em suas práticas pedagógicas e que encontraram no coletivo algumas respostas às suas buscas.

\section{O sujeito desejante}

A pesquisa de observação foi realizada por uma das autoras nos meses de novembro e dezembro de 2019 na cidade do Rio de Janeiro. Alguns fatos que serão relatados a seguir foram extraídos do diário de campo construído neste processo.

Como é típico desta época nesta região, o calor foi um elemento constante nos dias em que estive na presença das crianças. O Castelo, localizado no bairro de Santa Tereza, é um prédio sem elevador e, para chegar à torre, um terraço usado pelo coletivo, é preciso subir muitas escadas. Era comum que todos chegassem lá ofegantes e, claro, suando. Um certo dia, cheguei na mesma hora que a educadora 4 e o percurso das escadas foi feito conjuntamente. Ao chegarmos lá em cima, e obviamente constatarmos o calor, a educadora teve a ideia de encher uma piscina de plástico, deduzindo que as crianças iriam querer brincar quando chegassem. Fui, então, ajudar a ela a encher a piscina inflável, a pegar a mangueira e improvisamos um escorrega, com uma das tábuas que servem também de suporte para a mesa.

Uma a uma as crianças foram chegando, passando pela piscina e se sentando na área coberta. Era um dia em que duas crianças não haviam almoçado e a mãe de uma delas levou a comida para lá. Enquanto os dois meninos almoçavam, outros três se juntaram a eles, e começaram a conversar sobre alimentação. Enquanto isso, outra criança brincava sozinha de restaurante, com um fogão velho que existe no espaço.

Passei ali um bom momento olhando aquela cena e anotando em meu diário de campo sobre tudo aquilo. Era um dia muito quente, havia uma piscina disponível, e as crianças estavam sentadas em roda, conversando sobre o que haviam almoçado, sem a menor pressa de irem brincar.

Nesse momento, a educadora 4 olha para mim e diz: - Nossa, que vontade de saber o que você está anotando! Eu comecei a rir e disse a ela que estava mesmo observando a conversa despretensiosa dos meninos. Afirmei que se me contassem o que estava acontecendo naquele momento com as crianças, eu diria que qualquer criança iria correr para brincar, se molhar na piscina e que eles estavam ali, conversando calmamente. A educadora claramente não havia estranhado aquele movimento, e, quando foi chamada a atenção para este fato, ela falou: - É mesmo né! Eles têm isso... Primeiro se acolhem, sentam em roda. Têm uma coisa Revista Interinstitucional Artes de Educar. Rio de Janeiro, V. 7, N. 1 - pág. 427-446 janeiroabril de 2021: "Pedagogias Vitais: Corpo, Desejo e Educação" DOI: 10.12957/riae.2021.54833 
de circularidade, e os pequenos estão indo pelo mesmo caminho... Fiquei um tempão enchendo a piscina... E tá tudo bem (EDUCADORA 4).

A criança que estava brincando de restaurante começa a chamá-los para brincar e todos aceitam. Eles pedem a ajuda da educadora para fazerem o dinheiro. Sentam-se na mesa, pegam papeis, tesoura, lápis e caneta hidrocor e começam a criar cédulas. A educadora, então, ajuda a montar um cardápio em um pequeno quadro negro, com os pratos e os valores, os ensina sobre a soma daquelas cédulas, e quantas seriam necessárias para comprar cada item do cardápio. A brincadeira segue por quase uma hora. Quando o dinheiro acaba, eles se sentam e produzem mais, sempre assistidos pela educadora. Outras crianças chegam e pedem ajuda para também produzirem seu dinheiro. A piscina continua lá, sem a presença de nenhuma criança.

Tempos depois, as crianças correm, brincam de bola, até que surge a ideia de brincarem de caça fantasmas. Pegam suas mochilas e saem correndo pelo espaço. Uma das crianças se aproxima e pede para a educadora ajudá-la a colocar fogo em um papelão para caçar os fantasmas. A educadora fica preocupada e diz que o papelão é tóxico, que pode poluir o ar e sugere que ela brinque de criar pergaminhos com a vela. Ela aceita e se senta na mesa com uma vela, um fósforo e folhas de papel. A educadora acende a vela e explica para ela que por ser o fogo um elemento da natureza, é preciso ter calma para lidar com ele.

A criança coloca a folha de papel no meio da chama da vela e o papel pega fogo rapidamente. Eu me assusto e me levanto da mesa tentando ajudar, como um impulso de proteção. A educadora tira a folha da mão da criança, apaga o fogo e diz: - Você precisa ter calma, tenta pelas pontas, pega outra folha. A criança continua tentando queimar a folha e provocando chamas altas e a educadora continua pedindo para ela tomar cuidado, mas sem ameaçar acabar com a brincadeira. Ela própria começa a fazer de forma mais segura até que a criança também muda a sua forma de queimar o papel, conseguindo o formato de pergaminho. Ela fica muito empolgada com a produção, quando seus amigos decidem finalmente desfrutar da piscina. Ao ver o movimento deles, ela corre e grita: - Do fogo para a água! Se juntando ao grupo na piscina.

Esse momento, extraído do diário de campo, muito nos chamou a atenção por um motivo que parece estar naturalizado na prática dos coletivos parentais. As crianças buscaram, por elas próprias, momentos de brincadeiras que foram efetivos enquanto momentos de aprendizagem. Talvez, se elas tivessem entrado na piscina assim que chegaram, não teriam tido a oportunidade de aprender sobre as cédulas do nosso dinheiro, sobre a soma dos valores. Se a criança não quisesse caçar fantasma, não teria criado um pergaminho e se sentido tão Revista Interinstitucional Artes de Educar. Rio de Janeiro, V. 7, N. 1 - pág. 427-446 janeiroabril de 2021: "Pedagogias Vitais: Corpo, Desejo e Educação" DOI: 10.12957/riae.2021.54833 
feliz com a sua produção. Se a educadora, por sua vez, se sentisse frustrada com o fato de ninguém querer usar a piscina, e tivesse condicionado aquela ação, ela também não teria tido a oportunidade de trazer esses assuntos à tona.

Fernández (2001) esclarece que entre o ensinante e o aprendente é preciso haver um campo de prazer, em que o ensinante apresenta algo, mas é o aprendente que precisa reinventar o novo para conseguir apropriar-se dele. Assim, mais importante do que o conteúdo que está em jogo é a forma relacional que se extrai da subjetividade do aprendente. Logo, para que aquelas crianças pudessem se apropriar com prazer, se sentindo autoras de seus processos, foi preciso que a educadora desse espaço para as crianças assumirem o papel de sujeitos pensantes.

A autora aponta que a subjetividade envolvida na aprendizagem muitas vezes é esquecida, e que muitos ensinantes - que ela afirma que podem ser professores, pais, membros da família e companheiros da escola - tendem a despertar o interesse por aprender, baseados em senso comum, entendendo o estudo como uma simples necessidade. Desta forma, separa-se o prazer do processo de aprendizagem, causando nas crianças o não reconhecimento de seus próprios desejos de aprender (FERNÁNDEZ, 2001).

Mais do que apresentar conteúdos, a pessoa que ensina precisa abrir um espaço objetivo-subjetivo para aprender, baseado na construção de conhecimento e na construção de si mesmo, enquanto sujeito criativo e pensante (FERNÁNDEZ, 2001). Os primeiros ensinantes das crianças podem produzir esses espaços e transformar o aprender em autoria de pensamento, ou podem atrapalhá-lo ou até destruí-lo. Para que isso aconteça de forma positiva, Fernández (2001) esclarece que o ensinante deve ser alguém que acredita e quer que o conteúdo seja absorvido e ainda, deve criar as condições para o aprendizado acontecer.

Ficou evidenciado, durante a observação direta, o quanto o fato de a educadora do coletivo se retirar do centro do processo de aprendizagem colaborou para que as crianças ouvissem suas vozes, seus próprios desejos. Ao notarmos a educadora pacientemente observar o fluxo das crianças e, a partir dele, trazer à tona vários assuntos a serem ensinados, foi possível compreender como o papel do ensinante é importante dentro do coletivo.

Durante a observação direta feita neste coletivo, repensamos nosso papel enquanto educadoras e o quanto estamos acostumadas a centrar a condução do aprendizado nela. Vendo aquela educadora ali, pacientemente observar o fluxo das crianças e, com ele, trazer à tona vários assuntos a serem ensinados, nos fez compreender como o papel do ensinante é importante dentro do coletivo. Por mais que sua função não fique evidenciada a quem chega, é a educadora que permite que os processos de aprendizagem sejam realmente relevantes ali. Revista Interinstitucional Artes de Educar. Rio de Janeiro, V. 7, N. 1 - pág. 427-446 janeiroabril de 2021: "Pedagogias Vitais: Corpo, Desejo e Educação" DOI: 10.12957/riae.2021.54833 
Fernández (2001) afirma que a função principal do professor não é transmitir a informação que possui, mas sim proporcionar ferramentas e um espaço lúdico adequado para que a construção do conhecimento se torne viável. E é nesta atuação do professor que o aprendente será marcado ao longo da vida, se reconhecendo como sujeito pensante e autor de sua história. Para a autora, a energia desejante, a vontade, é o local onde se sustenta o aprender.

Exatamente por isso que os processos de aprendizagem são formadores de autoria, porque neles está o desejo de o sujeito conseguir apreender algo novo, já que "o essencial do aprender é que ao mesmo tempo se constrói o próprio sujeito" (FERNÁNDEZ, 2001, p. 31). $\mathrm{O}$ aprender entrega algo ainda mais subjetivo ao aprendente: o prazer. Quando se aprende algo que tanto desejou, o sujeito nutre-se do prazer de apropriar-se de sua autoria produtiva (FERNÁNDEZ, 2001). A alegria dos meninos comprando suas refeições imaginárias com o dinheiro construído por eles e a alegria da menina que dominou o fogo para criar o seu pergaminho, são exemplos do prazer de apropriação das suas autorias: "O jogar, o aprender e o trabalho criativo nutrem-se da mesma seiva e apropriam-se do mesmo saber-sabor" (FERNÁNDEZ, 2001, p. 31).

Assim, para compreender melhor a forma que a autoria de pensamento é desenvolvida nos coletivos, foi perguntado aos educadores o que eles entendem por esse termo. Aos pais, foi decidido apenas analisar se no conteúdo de suas falas apareceria algo que pudesse ser reconhecido como a autoria de pensamento, porque foi compreendido ser este um termo mais específico da educação do que do senso comum, como a criatividade, por exemplo.

Durante a análise do conteúdo das entrevistas dos educadores, os termos que mais surgiram ao designarem um conceito acerca da autoria de pensamento foi justamente o desejo.

[...] a autoria de pensamento é que vai, de repente, através da autoria de pensamento que eu vou ter minha criatividade né. A partir daquilo que eu acredito né, que eu gosto, que eu acho que deve ser, que eu vou usar a minha criatividade para fazer as coisas de acordo com que eu quero.(EDUCADORA 2, grifo nosso)

E ainda:

Pra mim autonomia de pensamento é isso, é o poder de decidir sobre a sua vontade e negociar com os demais né, com seus pares, colaborar com quem tá ali. [...] De você não impor a sua vontade e também você nãa ser subjugado, tipo assim, ninguém vai te obrigar nada. Nós vamos pensar como um coletivo o que que nós queremos enquanto o grupo porque é mais legal fazer agora. [...] Então você precisa ter uma autonomia de 
pensamento, do que eu quero, porque normalmente dizem pra gente o que a gente quer. A gente não é habituado a pensar, a escolher, eu não sou! Estou aprendendo agora né, a ter essa liberdade, essa autonomia de ser né, de estar, é isso acho que autonomia de pensamento é isso... (EDUCADORA 3, grifo nosso)

As educadoras envolvidas nos coletivos compreendem na prática o que Fernández (2001) destaca. De acordo com a autora, para que a tarefa de aprender seja bem-sucedida e proporcione o prazer de experienciar uma realização subjetiva, é preciso que o ensinante abra mão de impor um fim prático ao ato de aprender. A educadora da observação citada anteriormente não disse às crianças que criavam suas cédulas de dinheiro que eles estavam ali aprendendo Matemática e que esta é uma disciplina necessária para o aprendizado. Ela não fez contas em papel e nem os obrigou a repetir cálculos para verificar o aprendizado deles. Ela os ajudou a brincar, introduzindo ali na brincadeira elementos da Matemática. A aprendizagem, afirma Fernández (2001), é representada no corpo quando encontra o prazer pela autoria.

Para isso, é preciso que o ensinante saiba como sustentar o processo construtivo do aprender para dar espaço à autoria. É preciso que o adulto que ensina neutralize a sua importância no processo, estando ele próprio seguro de si mesmo. Assim, o ensinante não cria uma relação de dependência com o seu aprendente para se sentir feliz (FERNÁNDEZ, 2001).

Para além da educadora que montou uma piscina que não foi usada imediatamente pelas crianças, e não demonstrou estar frustrada com isso, outra educadora que atua a menos tempo em um dos coletivos, aponta como essa questão a inquietou inicialmente:

Eu tive muita dificuldade, tipo assim, ninguém fez a minha atividade... Ninguém tá ligando para mim, né? A gente como professora quer ser o centro das atenções. A criança não tá nem aí para você, ela te chama: Vamos? Vamos lá! Ela é dona, ela tem essa autonomia e você tá ali. E, tipo assim, para mim, tá sendo talvez mais difícil do que os outros que já estão habituados né, com essa metodologia. (EDUCADORA 3, grifo nosso)

Essa fala da educadora vai ao encontro do preconizado por Fernández (2001), quando ela afirma que o ensinante não deve fazer o mesmo que o aprendente, nem tampouco observálo passivamente. Mas que o papel de quem ensina é o de estar ao lado, de assumir o risco junto com o aprendente. Essa responsabilidade compartilhada traz consigo a eliminação da culpa para ambos os sujeitos envolvidos no processo.

[...] no coletivo ele pode ser quem ele quiser, quem ele é de verdade. Ele pode mostrar o seu melhor e o seu pior, digamos assim né, se existe um Revista Interinstitucional Artes de Educar. Rio de Janeiro, V. 7, N. 1 - pág. 427-446 janeiroabril de 2021: "Pedagogias Vitais: Corpo, Desejo e Educação" DOI: 10.12957/riae.2021.54833 
pior... Mas ele pode dar chilique, ele pode chorar, ele pode rir alto, ele pode correr sem parar se ele quiser, ele também pode ficar triste muitas vezes, ele pode mostrar quando ele tá bravo... então não tem ninguém ali moldando ele. Ele pode ser, pode viver todos os seus sentimentos e experiências né, que ele queira. (MÃE 4)

O conteúdo do discurso dessa mãe nos mostra o quanto seu filho se sente seguro dentro do ambiente que é gerado no coletivo e o quanto este espaço o exime de culpas. Ali ele consegue expressar sua verdadeira personalidade, sem medo de ser julgado. Para que o processo de aprendizagem aconteça, é preciso que se abra um campo de autorias, que gera liberdade. Sabe-se que um sujeito aprendeu quando ele não precisa mais de quem o ensinou e por isso aprender precisa de uma certa liberdade. Esta liberdade supõe responsabilidade que, por sua vez, acompanha a autoria (FERNÁNDEZ, 2001).

[...] como é um espaço que a criança vai direcionando seus interesses e vai se relacionando com aquilo que ela tem vontade, automaticamente é um espaço que permite a criatividade da criança né, já tá ali o espaço que tá aberto à criatividade. Não é um espaço que tá dizendo para criança que vai fazer, o que não vai fazer, quais são as normas, quais são os padrões, como tem que se comportar. É um espaço em que a criança é livre para ser quem ela tá com vontade. (MÃE 5)

A função do ensinante, neste caso, se transforma em um trabalho subjetivo de se oferecer como objeto transicional (FERNÁNDEZ, 2001). O objeto transicional, como afirma Winnicott (1975), é aquele que o bebê inicialmente supõe que cria quando a mãe o oferece. É um objeto que o bebê aprende a se relacionar de modo próprio, com a ilusão de tê-lo criado. É a partir dessa relação com o objeto transicional que o ser começa a compreender e criar as diferentes formas de lidar com o mundo. Por isso, Fernández (2001) relaciona o ensinante ao objeto transicional. $\mathrm{O}$ fato de a criança não precisar mais do objeto quando cresce para lidar com o mundo, está diretamente ligado ao fato do aprendente não precisar mais do ensinante, quando aprende: nesse papel subjetivo está implícito o processo de autoria. Sendo assim, seria o espaço do brincar o mesmo espaço de aprender, uma vez que ao brincar com o objeto transicional o bebê aprende a se relacionar?

A autora acima citada afirma que sim, o espaço é o mesmo, porém os processos se diferenciam, quando esclarece que "brincando descobre-se a riqueza da linguagem; aprendendo vamos apropriando-nos dela” (FERNÁNDEZ, 2001, p. 36). Brincando conseguimos inventar histórias ao passo que aprender é reconhecer-se, apreender suas crenças, constituir-se enquanto sujeito. O pensar transforma possível aquilo que é provável, 
transformando o que é desejado em provável. Ou seja, o que eu desejo eu transformo em provável, e o que é provável eu transformo em possível, a partir do pensar.

Fernández (2001) postula que para ser um professor "suficientemente bom", assim como aquela mãe suficientemente boa apresentada por Winnicott (1975), que ampara seu bebê em suas necessidades, o ensinante deve criar um espaço de brincar-aprender para seus alunos, ao mesmo tempo que cria este espaço para si. Para esta autora, quem ensina deve também gostar de aprender, e o espaço de aprendizagem deve abranger a potência do brincar e do aprender.

Isso somente se consegue com ensinantes que desfrutem o aprender, o brincar com as ideias e as palavras, com o sentido do humor, com as perguntas de seus alunos. Que não se obriguem à urgência de dar respostas certas; ao contrário, que consigam construir novas perguntas a partir das perguntas de seus alunos. (FERNÁNDEZ, 2001, p. 36)

Essa posição, que flutua entre ensinantes e aprendentes, é tema recorrente na fala tanto das educadoras, quanto dos pais entrevistados. Ao se criar um espaço coletivo, em que todos se envolvem nos processos de educação, é comum que, por vezes, os adultos se coloquem no lugar de aprendentes.

E também tem um processo que é uma auto-formação do adulto né, estar em coletivo não diz respeito às crianças somente... Diz respeito também a gente enquanto adulto. Essa convivência quase que diária com outras pessoas... Não na CasaEscola, mas eu já participei em outros quatro coletivos anteriores em que os encontros eram feitos nas nossas casas. Então assim, a gente abre a casa para estar recebendo essas pessoas diariamente. É muito aprendizagem mesmo né, da parte do adulto e que nesse processo aí que a gente tem oportunidade. Então para mim também, olhando um pouco para trás, assim né, do que me sempre me motivou muito tá em coletivo, é também um pouco disso assim de como é aprendizagem, do quanto a gente aprende nessas relações aí adulto-adulto, adulto-criança, enquanto educador né, enfim, tem muito uma formação minha assim, sem dúvida. (MÃE 5)

Os coletivos são construídos pelos adultos que se propõem a criar uma lógica outra de educação. Essas famílias se reúnem para aprender de que forma fazer o que acreditam, e é por isso que se confundem de forma produtiva entre ensinantes e aprendentes. A própria criação dos coletivos acontece de forma autoral em que adultos assumem o papel de aprendentes para conseguirem permitir que crianças se reconheçam em seus processos de aprendizagem.

Acho que a CasaEscola ela já é uma resposta, a uma... a um instinto criativo né porque quando a gente começa a CasaEscola a gente começa justamente

Revista Interinstitucional Artes de Educar. Rio de Janeiro, V. 7, N. 1 - pág. 427-446 janeiroabril de 2021: "Pedagogias Vitais: Corpo, Desejo e Educação" DOI: 10.12957/riae.2021.54833 
um ato de inventar um caminho próprio para pensar a educação dos nossos filhos, né. Para pensar, olhar os processos de aprendizagem dos nossos filhos com mais proximidade, de maneira autoral né. A gente pensa como que a gente gostaria que esse espaço fosse e a gente pratica isso né há 7 anos. Então dentro da CasaEscola né, os adultos eles são criadores criativos né, desse caminho, e abrem espaço para que as crianças sejam criadoras né, criativas o tempo todo no processo de aprendizagem delas mesmas né. (EDUCADORA 1)

As educadoras que não são familiares integrantes do coletivo, e que por isso não participaram dos processos iniciais que fundaram os espaços, também precisam aprender a se reconfigurar nesta lógica, enquanto profissionais. Elas conseguem realizar a tarefa postulada por Fernández (2001) de fazer consigo, como professor, o mesmo que propicia para seus alunos. Permitem-se brincar, jogar e aprender, criando um espaço de potência criativa: “Eu assim, eu costumo dizer que lá eu não ensino nada, eu só aprendo. Eu saio de lá todo dia aprendendo muita coisa" (EDUCADORA 2).

Esse sentimento é comum à outra educadora, demonstrado em diferentes momentos da entrevista: "Então lá, tá, eu sou a pedagoga, eu tô lá, mas eu mais aprendo do que ensino né?" E ainda: “Tudo é aprendizado... Eu aprendo mais que ensino" (EDUCADORA 3).

Este campo aberto de ensinamentos e aprendizagens se torna produtor de um prazer que engloba todo o processo, e que é tão essencial para que gere autoria de pensamento. É na forma de se colocarem enquanto aprendentes que as educadoras permitem que as crianças sejam protagonistas de seus momentos de aprendizagem, porém, mantendo suas funções enquanto ensinantes, ao captarem o espaço em que se abre o aprender.

É importante lembrar que Fernández (2001) afirma que, para que a autoria de pensamento aconteça, é preciso que o sujeito se reconheça enquanto protagonista daquela produção, que pode ser um texto, uma história, um desenho, um exercício de Matemática. Mas é importante que nesta produção ocorra o reconhecimento de si mesmo, para que a produção se realize e para que quem a produziu se responsabilize por ela.

Reconhecer-se autor de seu pensamento é o caminho para a formação de um sujeito autônomo. A base da autonomia está no reconhecimento de seu inconsciente, da subjetividade que o compõe enquanto sujeito. Por isso, a autoria de pensamento é requisito para o desenvolvimento da autonomia (FERNÁNDEZ, 2001).

Fernandéz (2001) assinala que o pensamento não é autônomo porque é ancorado no desejo, e por isso se reconhecer pensante é se reconhecer desejante. Quando a criança começa a reconhecer seus desejos, para, a partir dele, pensar como torná-lo possível, passa a se 
desenvolver aí a sua autonomia. Ela deixa de ser sujeito que atende aos desejos dos outros para ser, ela mesma, sujeito desejante e, logo, pensante (FERNANDEZ, 2001).

Durante uma entrevista com uma família em que pai e mãe quiseram estar juntos no vídeo para responderem às perguntas, a filha do casal que participa de um dos coletivos esteve também presente e, ao contarem sobre a sua experiência primária em uma creche regular, a menina falou: "eu já era sincera, eu falava, quando eu chegava em casa eu falava: Mamãe, eu dormi meio, eu comi meio, eu fiz tudo meio". E a mãe completa: “É, a Filha 1 tava na adaptação dela. Foi assim né, tudo que ela fazia era meio... era um pouco do que ela queria, e um pouco do que eles queriam... É isso." (MÃE 1).

Essa fala nos chamou muito a atenção quando a própria menina relata que se sentia objeto do desejo do que a escola esperava dela, ao mesmo tempo que entendia que aquilo não fazia parte do seu próprio desejo. Ainda sobre uma formação autônoma, a Educadora 3, a mais nova em experiência com coletivos, nos coloca o quanto ela, enquanto profissional, está nesse local de estranhamento ao se deparar com o questionamento da sua própria autoria de pensamento:

Não é uma coisa fácil, admito, porque eu aprendi a pensar por mim na faculdade né? Você vem sendo tolhido a vida toda. Todo mundo te diz o que que você tem que fazer, como você tem que agir, como que você tem que ser, e aí vem um monte de estereótipos né, sociais... Aí você começa a pensar: não, eu quero isso, eu quero aquilo, será se isso é bom, já adulta. E lá no projeto você vê isso numa criança pequena de dois anos, de três anos, ela fala para você: não vou! E com toda, assim, com uma certeza e você fica como? Você fica ali paralisada. (EDUCADORA 3)

Essa paralisação que a Educadora 3 admite, acontece quando ela se depara com a realidade de uma infância não vivida por ela. Ela assume que, em seu processo de amadurecimento, foi sendo guiada, tolhida pelo desejo de outras pessoas. O pensamento, conforme esclarece Fernández (2001, p. 91), não pode ser autônomo porque está incorporado no desejo. "Pensar supõe entrar nos desejos, vendo o possível e o impossível, para depois poder trabalhar na direção de fazer provável algo do possível”.

É por isso que, quanto mais cedo o sujeito aprende a se reconhecer enquanto sujeito desejante, mais cedo caminha para sua autonomia. É preciso que, em qualquer ambiente de aprendizagem, se mude o paradigma de ensino. O paradigma educacional parte do pressuposto de que o professor deve trabalhar o conteúdo de forma clara, concreta e concisa. São os três "C" apontados por Fernández (2001). Porém, esse processo entende o ensinante como passivo de seu processo de aprendizagem, sendo que na verdade é preciso que o sujeito Revista Interinstitucional Artes de Educar. Rio de Janeiro, V. 7, N. 1 - pág. 427-446 janeiroabril de 2021: "Pedagogias Vitais: Corpo, Desejo e Educação" DOI: 10.12957/riae.2021.54833 


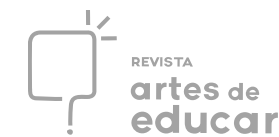

que ensina "se mostre conhecendo e não conhecedor; que se mostre pensante e não que exiba e imponha o que pensa" (FERNÁNDEZ, 2001, p. 92).

Para alcançar este ideal, a autora afirma que a educação precisa reconhecer a existência de outros quatro "C": complexo, contextualizado, conflitivo e questionado (cuestionado, em espanhol); e que abarque ainda outros dois "C" de confusão e caos, uma vez que o tão desejado "C" de criatividade só surge quando se aceita e produz os outros seis "C" (FERNANDÉZ, 2001). Por isso, o ensinante precisa reconhecer em si e nos seus alunos a capacidade pensante, mesmo quando ela não está visível, mesmo quando estão todos em silêncio.

Outro relato do diário de campo aqui apresentado que nos chama atenção é o momento em que as crianças entram no Museu de Arte do Rio, e acontece a seguinte cena.

A entrada do Museu é feita por uma longa rampa. Assim que a educadora abriu a porta para a passagem na rampa, todos deitaram-se no chão e começaram a descer rolando. Diante do meu espanto, a Educadora 1 que nos acompanhava me disse: "Eles sempre descem assim, é um ritual deles." No mesmo instante, uma senhora que subia a rampa parou para tirar fotos daquela cena dizendo para nós: - Eles vivem o Museu!

Não pude deixar de ser atravessada, neste momento, pela minha formação de produtora cultural com experiência em educação de museus. Quantas vezes me senti frustrada ao ver que, o que era pensado nestes espaços museais, enquanto espaços de educação, não eram muitas vezes consumidos pelo público, ou que a experiência do museu era vivida de forma superficial, sem efetivamente transformar aqueles sujeitos que por ali passavam? Decerto quem criou a rampa de entrada do Museu pode não ter pensado em crianças ali rolando por ela, mas não seria essa uma forma de apropriação do espaço? As crianças ali não estavam criando a sua relação de consumir aquela proposta?

Enfim, ao entrarem no museu, a Educadora 1 pediu que eles falassem baixo para não atrapalhar os demais visitantes e as crianças se espalharam, cada uma atraída por uma obra diferente. Até que uma delas disse: “- Tem um cara morto no filme ali." E todas correram, se juntaram e se sentaram na frente da tela. O filme em questão era Terra em Transe, do diretor Glauber Rocha. Um filme em preto e branco, lançado em 1967 que traz duras críticas políticas ao contexto de sua época.

As crianças atentas, travaram o seguinte diálogo sobre o filme:

- Eles estão pelados!

Revista Interinstitucional Artes de Educar. Rio de Janeiro, V. 7, N. 1 - pág. 427-446 janeiroabril de 2021: "Pedagogias Vitais: Corpo, Desejo e Educação" DOI: 10.12957/riae.2021.54833 
Uma criança ri.

- Eu não acho engraçado.

- Nem eu.

- É, são índios.

- Achei que eles estavam tentando pegar algo.

- Olha, já matou um monte.

- São os brancos!

- Que horrivel!

- Esses são os brancos.

- São de Portugal.

- É o português rei.

- Nossa, que ditador!

Nesse momento, as crianças se deitam no chão e continuam com suas impressões, até que a educadora se aproxima e explica o contexto do filme. Ao permitir que as crianças primeiro produzissem suas impressões sobre o que estavam ali assimilando, a educadora permite a elas se expressarem enquanto sujeitos pensantes. Mesmo o filme não sendo adequado àquela idade, as crianças conseguiram criar um enredo que não muito se destoa do que foi apresentado. A educadora, então, a partir das construções iniciais das crianças, explica o conteúdo para elas. Fernández (2001) mostra que o sujeito só se faz autor se sua produção for interpretável, e aquele que só repete o que ouve não conseguirá assumir uma posição de autor.

Os coletivos proporcionam às crianças um espaço-tempo em que se produzem sujeitos autônomos, criativos e autores uma vez que permitem esse tempo de brincar. Esse tempo de explorar conteúdos de museus, de explorar brincadeiras que emergem do seu cotidiano, de explorar objetos que não são postos como prontos. "Para controlar o que está fora, há que fazer coisas, não simplesmente pensar ou desejar, e fazer coisas toma tempo. Brincar é fazer” (WINNICOTT, 1975, p. 69).

Fernández (2001, p. 127) afirma que “a primeira experiência de autoria é o brincar”. O brincar existe porque está posto e para que ele aconteça não é necessário a demanda ou a exigência do outro. É assim que surge o espaço potencial, a zona transicional postulada por Winnicott (1975). É neste espaço que o ser, desde bebê, começa a brincar e se relacionar com o seu corpo, criando uma experiência de autoria. O brincar permite que o sujeito realize a experiência de transformar o objeto em outra coisa, transformar a realidade aceitando os seus limites impostos. O pensamento surge neste momento de criar soluções para os limites da realidade (FERNÁNDEZ, 2001). 
O movimento de ficar só é fundamental para se reconhecer autor de seus pensamentos. Esta capacidade é resultado da experiência vivida na infância de ficar sozinho em companhia da mãe. Essa experiência surge do paradoxo de estar só com outra pessoa, pois é preciso que haja alguém disponível, mesmo sem exigir nada. Isso gera a maturidade e a capacidade de estar a sós em um sujeito em que foi sustentado em um ambiente saudável (WINNICOTT, 1975).

Essa figura adulta que deixa a criança estar só, estando perto, se faz presente nos coletivos, tanto na figura das educadoras, quanto na figura dos pais que ali estão. Em todos os momentos que haviam pais presentes, acompanhando o grupo ou porque faziam parte do rodízio, foi possível observar que eles também se colocavam como figura que dá suporte ao processo das crianças, e não a que é o centro do processo. Fernández (2001) avalia que o psicopedagogo deve estar disponível diante da criança que necessita ficar sozinha, sem exigir nada dela, e que para isso é preciso que o adulto se conecte com a sua própria capacidade de ficar sozinho. É daí que surge o espaço potencial, o "entre", aquele espaço do qual emerge a brincadeira e a autoria de pensamento.

O espaço potencial de Winnicott (1975) implica uma nova configuração do brincar, dando a ele uma função subjetivante. Como o autor definiu o espaço potencial como o lugar do jogo, da criatividade, inserindo no brincar este papel subjetivante, Fernández (2001) conclui que talvez não tenha sido postulado um tempo transicional porque este emerja do aprender, uma vez que a aprendizagem é tempo, é devir.

A brincadeira traz consigo a possibilidade da criação, dando à criança a oportunidade de construção e reconstrução de si mesma. "O corpo brinca o saber do desejo e o desejo de saber" (FERNÁNDEZ, 2001, p. 131). Por isso, a educação deve prezar pela energia de um corpo autor de sua própria história (FERNÁNDEZ, 2001). Um corpo livre para brincar, para reconhecer seus desejos a partir dos seus pensamentos, da transformação do provável. E é neste caminho que os coletivos seguem, acreditando que é a partir do livre brincar que crianças e adultos desenvolvem sua criatividade e autoria de pensamento, tornando-se sujeitos de suas próprias histórias.

\section{Considerações Finais}

Quando algumas famílias amigas se viram passando pela mesma etapa de vida, a de ter um filho pequeno, precisando de cuidados, no momento de volta ao trabalho, surge a ideia Revista Interinstitucional Artes de Educar. Rio de Janeiro, V. 7, N. 1 - pág. 427-446 janeiroabril de 2021: "Pedagogias Vitais: Corpo, Desejo e Educação" DOI: 10.12957/riae.2021.54833 


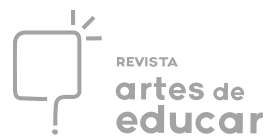

de criar um coletivo para atender aos cuidados das crianças. Estes coletivos se iniciam de forma quase natural, para que cada família pudesse se responsabilizar pelo grupo de bebês um dia na semana, enquanto as outras famílias pudessem atender as demandas do trabalho.

Esse lugar de cuidados acaba por reunir pessoas que possuem críticas muito semelhantes ao contexto contemporâneo que a sociedade vive. Muitos querem desacelerar, querem participar mais da vida dos filhos, querem trabalhar, mas com horários que permitam o convívio em família. Forma-se então um grupo que luta contra um sistema capitalista, em que ter é mais importante do que ser.

Essas pessoas percebem que precisam fugir desta lógica e que, para isso, é preciso também que seus filhos estejam inseridos em outros processos de educação para além da escola. A instituição formal de ensino muitas vezes vem atender a essa demanda social, de formar pessoas capazes de sustentarem o sistema capitalista.

Algumas instituições exigem que crianças pequenas se adaptem a horários rígidos, desenvolvam habilidades motoras o mais cedo possível, aprendam línguas estrangeiras e se comportem de forma controlada, para atender a uma sociedade sem tempo para brincadeiras. A brincadeira, para essa sociedade atual, gera bagunça, gera barulho, exige disposição e principalmente, tempo. E o tempo se transformou em um bem extremamente valioso, os adultos não podem se dar ao luxo de o desperdiçarem com brincadeiras.

$\mathrm{Na}$ contramão deste caminho, estão os coletivos parentais. Aquele grupo de pais e mães que começaram despretensiosos se revezando nos cuidados dos filhos, passam a estudar sobre educação, ao perceberem o campo fértil que se cria, ao se juntar crianças e adultos dispostos a gastarem seu tempo livre para brincar. É claro que este olhar se torna possível porque estas famílias estão inseridas em uma classe de privilégios sociais. Todos possuem Ensino Superior completo, muitos vão além, com cursos de pós-graduação, e a maioria tem formação em áreas de ensino e educação. Evidencia-se, assim também, se tratar de um grupo que faz parte da classe média brasileira, destoando da maior parte da população do país, que compõe as classes baixas da sociedade.

Os grupos, portanto, possuem condições intelectual e financeira de suportarem um espaço que experimenta a brincadeira como o principal veículo de aprendizagem. Estas famílias sustentam a ideia de que quanto mais livre as crianças puderem estar, mais rico serão seus processos de aprendizagem. Ao longo de sete anos, tempo de existência do coletivo mais antigo pesquisado, é inegável o quanto se produziu de práticas que colaboram para o desenvolvimento da criatividade e da autoria de pensamento de todos os envolvidos no processo.

Revista Interinstitucional Artes de Educar. Rio de Janeiro, V. 7, N. 1 - pág. 427-446 janeiroabril de 2021: "Pedagogias Vitais: Corpo, Desejo e Educação" DOI: 10.12957/riae.2021.54833 


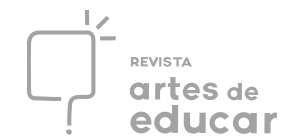

Ao iniciar esta pesquisa, tinha-se em mente voltar o olhar para as crianças, para conseguir compreender de que forma são trabalhadas as questões de ludicidade nestes espaços. Ao longo das observações feitas, muito rapidamente foi percebido que os adultos também são parte importante neste processo. A começar pela própria construção do modelo de existir dos coletivos. Os adultos envolvidos na criação destes lugares foram extremamente criativos, autores e, claro, corajosos ao subverterem uma lógica social, colocando suas próprias famílias para testarem suas teorias. Esse destemor, próprio dos sujeitos autônomos, que se reconhecem e se responsabilizam por suas criações, fez surgir um local de experimentações capaz de gerar liberdade e confiança nas crianças para que se construam enquanto sujeitos também autônomos e criativos.

Os coletivos geram, todos os dias, um espaço lúdico, um espaço potencial, onde habita a brincadeira, em que crianças se sentem capazes de fruir sua criatividade, no contato com diferentes objetos, diferentes sujeitos e diferentes ambientes. As crianças reconhecem as suas subjetividades enquanto deixam externar suas realidades internas, refletidas nas suas brincadeiras e produções, que se constroem a partir das interações com o outro e com o meio.

Mediando este brincar e identificando os momentos ricos em aprendizagem, estão adultos que se dispuseram a se reinventar enquanto educadores. Profissionais da educação que aprenderam a difícil missão de se retirar do centro do processo de aprendizado, e desenvolver uma escuta ativa e empática às necessidades e curiosidades das crianças.

Talvez, nestes adultos esteja o ponto chave para a criatividade das crianças. É a partir destes sujeitos que todo o processo acontece. A "mãe suficientemente boa", na função ali de educador, ampara aquelas crianças em seus processos de liberdade e frustração, fazendo com que elas se sintam seguras em demonstrar suas subjetividades. Esse processo só se torna possível quando o próprio educador consegue trabalhar as suas frustrações não acolhidas, e compreender o que o compõe enquanto sujeito criativo e autônomo.

Os educadores assumem o papel de objeto transicional, permitindo que as crianças os usem para transformar a realidade, quando ela parece ser ameaçadora, e os dispensem quando criam formas de lidar com o desconhecido. Neste movimento de se fazer presente, e se de fazer ausente, mas sempre na companhia das crianças, é que o educador deixa emergir as realidades internas das crianças, que, em contato com a realidade externa, cria a terceira dimensão do sujeito: o espaço do brincar.

Pode-se concluir, portanto, que os coletivos parentais se apoiam na construção diária do espaço potencial, para que crianças e adultos sejam capazes de desenvolver a sua criatividade e sua autoria de pensamento, ancorados no brincar, fazendo emergir assim, Revista Interinstitucional Artes de Educar. Rio de Janeiro, V. 7, N. 1 - pág. 427-446 janeiroabril de 2021: "Pedagogias Vitais: Corpo, Desejo e Educação" DOI: 10.12957/riae.2021.54833 
momentos sólidos de aprendizagem. Estes momentos são sustentados por ensinantes que se permitem viver o papel de aprendentes para reconhecer as diversas realidades trazidas pelas crianças que podem ser transformadas em aprendizados efetivos para todo o grupo.

\section{REFERÊNCIAS}

ANDRÉ, M. E. D. A. Etnografia da prática escolar. Campinas: Papirus, 2009.

BARDIN, L. Análise de Conteúdo. Tradução: Luís Augusto Pinheiro. São Paulo: Edições 70, 2016.

CHAMUSCA, C. M. C. Um Estudo Sobre os Coletivos Parentais do Rio de Janeiro. 2019. 134f. Dissertação (Programa de Pós-Graduação em Educação) Universidade Federal do Rio de Janeiro, Rio de Janeiro, 2019.

FERNANDEZ, A. O saber em jogo: a psicopedagogia propiciando autorias de pensamento. Porto Alegre: Artmed, 2001.

GOHN, M. G. Educação Não-Formal e o Papel do Educador (a) Social. In: Revista Meta: Avaliação, [S.1.], v. 1, n. 1, p. 28-43, junho 2009. Disponível em: http://revistas.cesgranrio. org.br/index.php/metaavaliacao/article/view/1. Acesso em: 10 de agosto de 2020.

WINNICOTT, D. W. O brincar e a realidade. Rio de Janeiro, RJ: Imago, 1975

\footnotetext{
${ }^{\text {i }}$ Professor Associado da Universidade Federal do Rio de Janeiro, da Faculdade de Educação e do Programa de Pós-graduação em Educação da UFRJ. Coordenadora e fundadora do grupo de pesquisa Criar e Brincar: LUPEA e do Espaço de Atendimento Psicopedagógico (EAP) ao aluno da Faculdade de Educação da UFRJ. Pósdoutoranda em Design Pedagógico pela Pontifícia Universidade Católica do Rio de Janeiro (2019), Doutora em Psicologia Clínica pela Pontifícia Universidade Católica do Rio de Janeiro (2005), Mestre em Letras pela PUCRio (1986). Graduada em Psicologia pelo Centro Universitário de Brasília (1998) e em Letras pela PUC-Rio (1982). E-mail: mariavitoriamaia@gmail.com. ORCID ID: 0000-0002-9697-8243. Rio de Janeiro, Brasil.

ii Mestre em Educação pela Universidade Federal do Rio de Janeiro. Pesquisadora do grupo de pesquisa Criar e Brincar: LUPEA da Universidade Federal do Rio de Janeiro. Graduada em Produção Cultural pela Universidade Federal Fluminense (2014) e Licenciada em Artes pela Faculdade Alfamérica (2017). E-mail: dudabainha@gmail.com. ORCID ID: 0000-0002-3408-3575. Rio de Janeiro, Brasil.
} 